\title{
Pengaruh Pretend Play dan Jenis Kelamin terhadap Kemampuan Berpikir Divergen Anak Usia 5 - 6 Tahun
}

\author{
Astri Chintya Astana ${ }^{\bowtie} 1$, Rien Syafrina ${ }^{2}$, Karnadi ${ }^{3}$ \\ Pendidikan Anak Usia Dini, Universitas Negeri Jakarta \\ DOI: $10.31004 /$ obsesi.v4i2.417
}

\begin{abstract}
Abstrak
Penelitian ini bertujuan untuk memperoleh data secara empiris tentang pengaruh pretend play (bermain pura - pura) dan jenis kelamin terhadap kemampuan berpikir divergen anak usia 5-6 tahun. Penelitian ini menggunakan pendekatan kuantitatif dengan menggunakan metode eksperimen dengan rancangan factorial $2 x 2$, dengan variabel terikat dalam penelitian ini adalah kemampuan berpikir divergen anak sedangkan variabel bebasnya pretend play dengan variabel atribut adalah yang terdiri dari 2 (dua) taraf yaitu jenis kelamin yang terdiri dari perempuan dan laki - laki. Sampel dalam penelitian ini yaitu anak kelas TK B orange dan apple di Taman Kanak-Kanak Kristen Cahaya Bangsa tahun pelajaran 2018/2019 yang terdiri dari 39 orang. Hasil penelitian ini menunjukan bahwa terdapat pengaruh yang signifikan pada pretend play dan jenis kelamin terhadap kemampuan berpikir divergen.
\end{abstract}

Kata Kunci: kreativitas, berpikir divergen; bermain pura - pura; jenis kelamin.

\begin{abstract}
This study aims to obtain empirical data about the effect of pretend play and gender on the divergent thinking abilities of children aged 5-6 years. This study uses a quantitative approach using an experimental method with a $2 \times 2$ factorial design, with the dependent variable in this study is the divergent ability of children to think while the independent variable is pretend play with the attribute variable consisting of 2 (two) levels, namely sex consisting of women and Male. The samples in this study were K2 orange class and apple class in TK Kristen Cahaya Bangsa 2018/2019 academic year consisting of 39 people. The results of this study indicate that there is a significant influence on pretend play and gender on divergent thinking abilities.
\end{abstract}

Keywords: Creativuty, Divergent Thinking, Pretend play, gender

Copyright (c) 2019 Astri Chintya Astana

$\triangle$ Corresponding author :

Email Address : riafransisca89@gmail.com (Jakarta, Indonesia)

Received 19 December 2019, Accepted tanggal bulan tahun, Published tanggal bulan tahun

\section{PENDAHULUAN}

Perkembangan dunia yang pesat membawa manusia menghadapi berbagai keadaan dan kebutuhan yang semakin kompleks menyebabkan transformasi dari nilai konvensional ke modern. Salah satu perubahan nilai yang dirasakan saaat ini adalah munculnya aneka pekerjaan yang tidak ada di masa lalu namun menjadi kebutuhan di masa sekarang, misalnya praktisi dunia digital atau market research. Seorang profesor dari IE Bussiness School mengatakan bahwa pekerjaan yang ada di masa mendatang, tahun 2025, adalah 
pekerjaan yang tidak ada di masa sekarang (Boehm, 2017). Globalisasi dan perdagangan bebas juga merupakan dampak dari perkembangan dunia ini. Berkaitan dengan isu globalisasi dan abad 21, berbagai pihak membahas mengenai keterampilan yang perlu dipersiapkan menghadapi hal tersebut.

Pernyataan yang disebutkan Jennifer Levin dan Goldberg (Levin-Goldberg, 2012) bahwa pada abad 21, karyawan diminta untuk dapat kritis dalam berpikir dan memecahkan masalah, komunikasi, kolaborasi, serta kreativitas dan inovasi. Berkaitan dengan kreativitas, Martin Prosperty Institute dalam jurnalnya menyatakan bahwa Indonesia menduduki peringkat 115 dari 139 pada Global Creativity Index tahun 2015. Global Creativity Index ini menunjukkan tingkat perkembangan teknologi, talenta dan tolerasi. Sedangkan pada poin kelas kreatif dibandingkan dengan negara - negara di asia tenggara, Indonesia menduduki peringkat kedua akhir. Hal ini memperkuat bahwa sebagai negara berkembang, Indonesia perlu mengembangkan individu yang kreatif (Florida, Mellander, \& King, 2015).

Seluruh individu perlu mempersiapkan diri untuk menghadapi tantangan di abad 21, tidak terkecuali laki - laki dan perempuan. Berkaitan dengan itu jenis kelamin merupakan salah satu faktor yang mempengaruhi kreativitas. Kyung Hwa-Lee mengatakan bahwa terdammpat perbedaan signifikan pada kemampuan berpikir kreatif anak perempuan dan laki - laki. Anak perempuan memiliki skor yang lebih tinggi kemampuan berpikir kreatif dalam menggambar serta berbahasa dibandingkan anak laki - laki (Lee, 2005). Pernyataan lain yang mendukung hal ini diungkapkan oleh Cramond dan rekanrekannya dalam jurnal The Gifted Child Quarterly. Berdasarkan hasil analisis penelitianya ditemukan adanya perbedaan baik pada aspek fluency, flexibility, originality, dan elaboration. Perempuan memiliki kecenderungan lebih tinggi pada aspek fluency, originality, dan elaboration, sedangkan pada laki - laki cenderung lebih tinggi pada aspek flexibility meskipun perbedaannya tidak terlalu signifikan (Cramond, Matthews-morgan, Bandalos, \& Zuo, 2005). Teresa Artola (Artola, 2015) dalam penelitiannya mengenai perbedaan memberikan hipotesis bahwa ketika dihadapkan pada tugas-tugas yang memerlukan penggunaan imajinasi, anak laki-laki dan perempuan bereaksi dengan cara yang berbeda. Anak laki-laki biasanya fokus pada tindakan sementara anak perempuan fokus pada perasaan dan emosi dan juga tanggapan mereka jauh lebih deskriptif dan memasukkan lebih banyak detail. Hasil penelitiannya menunjukkan bahwa perempuan memperoleh skor yang lebih baik daripada laki-laki dalam kelancaran, fleksibilitas, dan dalam beberapa kelompok, juga pada aspek orisinalitas. Perbedaan-perbedaan ini lebih kuat pada siswa yang lebih muda, dan menghilang pada mahasiswa dan orang dewasa.

Melihat hal tersebut baik anak perempuan dan laki - laki perlu diberikan stimulasi yang tepat untuk meningkatkan kreativitasnya. Pemberian stimulasi dapat dilakukan sejak usia dini. Penelitian yang dilakukan oleh Renata Rudine, et al. juga mengatakan bahwa kreativitas dimulai sejak usia muda yaitu taman kanak - kanak (Rudienė, Volkovickienè, \& Butvilas, 2016). Dengan memiliki kreativitas, anak dapat bertahan dan berkembang dalam kompetisi bebas, sementara pada saat bersamaan mereka dapat berkolaborasi dan memecahkan masalah bersama anak lain dari seluruh bagian dunia.

Mengembangkan kreativitas anak berarti mengembangkan kemampuan berpikir anak. Anak memiliki kemampuan berpikir tinggi, akan menghasilkan gagasan, jawaban, atau pertanyaan yang bervariasi. Saat dihadapkan dengan suatu masalah, anak dapat melihat masalah dari berbagai sudut pandang. Salah satu produk kreativitas adalah divergent thinking atau berpikir divergen. Beberapa penelitian mengenai kreativitas menggunakan aspek pada divergent thinking sebagai pengukurannya. Runco dan Acar (2012) membahas mengenai Divergent thinking sebagai potensi kreativitas (Runco \& Acar, 2012). Kriteria pada aspek - aspek berpikir divergen mengarah pada kreativitas sehingga sering digunakan sebagai tes untuk mengukur kreativitas. Meski begitu, divergent thinking bukanlah persamaan kata dari kreativitas melainkan dapat memberikan informasi yang dapat memprediksi potensi kreativitas seperti yang disampaikan Runco dan Acar bahwa 
Indikator berpikir divergen atau divergent thinking sering mengarah kepada potensi kreativitas misalnya originalitas. Sejalan dengan pendapat tersebur Hocevar dalam Runco (Runco \& Acar, 2012) mengidentifikaskan empat tipe tes kreativitas yaitu, tes berpikir divergen, tes sikap dn tes biografi.. Hoffman dan Russ (Hoffmann \& Russ, 2012) juga mengatakan bahwa berpikir divergn merupakan produk dari kreativitas. Dalam menghasilkan produk kreatif memungkinkan terdapat pemikiran yang divergen. Ketika individu berusaha mencari ide - ide yang berbeda dan di luar dari kebanyakan, individu mengalami proses berpikir divergen.

Guilford (dalam Munandar, 2009)) menyatakan kreativitas merupakan kemampuan berpikir divergen menjajaki bermacam-macam alternatif jawaban terhadap suatu persoalan, yang sama benarnya. Pendapat Guilford ini mengarah kepada kreatifitas kemampuan berpikir divergen. Meskipun aspek berpikir divergen sering digunakan untuk memprediksi kreativitas, namun berpikir divergen bukan persamaan kata dari kreativitas (Runco \& Acar, 2012). Berpikir divergen hanyalah satu bentuk kreativitas (Hoffmann \& Russ, 2012)Teori umum berpikir divergent dapat ditemukan dalam teori-teori yang kembali ke abad ke-19, tetapi J. P. Guilford (1950, 1968) yang dengan jelas mengaitkan produksi yang berbeda dengan potensi kreatif. Dia berhipotesis beberapa komponen untuk berpikir divergen (Runco \& Acar, 2012). Guilford (Michalopoulou, 2014)menyatakan bahwa tindakan berpikir dapat dibagi menjadi dua kategori dasar: 'faktor memori' dan 'faktor pemikiran'. Ketika menggunakan faktor-faktor pemikiran, maka individu dapat membedakan antara berpikir konvergen dan berpikir divergen. Faktor memori mencakup generasi ide dan peristiwa baru dari informasi yang diketahui, sedangkan faktor pemikiran mengacu pada ide atau data baru, dengan koneksi minimal ke informasi yang diketahui. Pemikiran konvergen adalah proses yang berbeda dari pemikiran divergen. Pemikiran konvergen menghasilkan hanya satu jawaban yang dikonfirmasi benar, dan mengarah pada jalur formal ratifikasi dan konfirmasi pengetahuan, sedangkan pemikiran divergen memungkinkan berbagai jawaban untuk suatu masalah, tanpa metode penggunaan tunggal yang ditentukan.

Pendapat Russ mengenai kemampuan berpikir divergen bahwa kemampuan untuk menghasilkan banyak ide, untuk mencari ingatan seseorang secara luas, dan untuk berpikir secara fleksibel meningkatkan peluang bahwa produsen akan menyelesaikan masalah secara kreatif atau menghasilkan karya seni (Russ \& Wallace, 2013). Kemampuan berpikir divergen juga satu hal yang dianggap penting dalam produksi kreatif (Hoffmann \& Russ, 2012). Russ (Russ \& Wallace, 2013)mengatakan "Divergent thinking, broad associative skill, insight, cognitive flexibility, and perspective taking. Divergent thinking, an important ingredient of creative production, involves the ability to generate a variety of ideas. Menurut Russ, berpikir divergen merupakan kemampuan berpikir luas dan dapat menghubungkan satu dengan yang lain, serta memiliki keluwesan dalam berpikir dan pengambilan persfektif. Menurutnya berpikir divergen merupakan unsur penting dari produksi kreatif, melibatkan kemampuan untuk menghasilkan berbagai ide.

Runco berpendapat bahwa berpikir divergen melibatkan asosiasi bebas, kemampuan pemindaian yang luas, dan kelancaran berpikir, dan telah ditemukan relatif independen dari kecerdasan menjadikan pemikiran yang berbeda sebagai salah satu ukuran paling populer dari potensi kreatif (Hoffmann \& Russ, 2012). Berpikir divergen mengacu pada hal - hal yang berbeda dari yang biasa dan merupakan alat yang berharga dalam menyelesaikan masalah serta metode berpikir yang bertujuan untuk menghasilkan banyak ide tentang satu topik dalam rentang waktu yang relatif singkat (Sharma, 2015).

Produktivitas kreatif dipengaruhi oleh variable majemuk yang meliputi faktor sikap, Guilford membedakan antara ciri - ciri bakat (apptituted trait) dan ciri - ciri non bakat (non apptituted trait) yang berhubungan dengan kretivitas. Aspek berpikir divergen meliputi empat kriteria, antara lain kelancaran, kelenturan, keaslian dalam berpikir dan elaborasi atau keteperincian dalam mengembangkan gagasan (Munandar, 2009). Sebagian besar tes berpikir divergen sekarang hanya terlihat pada kelancaran (fluency), kelenturan (flexibility), 
keaslian (orginality) dan elaborasi atau keteperincian, bahkan, terlalu sering hanya kelancaran yang digunakan.

Guilford mendefinisikan kelancaran sebagai kemampuan untuk menghasilkan banyak gagasan dan jawaban penyelesaian dan suatu masalah yang relevan, arus pemikiran lancar. Dalam kelancaran berpikir, yang ditekankan adalah kuantitas, dan bukan kualitas. Menurutnya kelancaran merupakan kemampuan memproduksi secara divergen unit - unit simbolik dan semantic (Runco \& Acar, 2012). Sejalan dengan pendapat Guilford, menurut Jamaris kelancaran merupakan kemampuan untuk memberikan jawaban dan mengemukkan pendaat atau ide - ide dengan lancar (Jamaris, 2010). Sedangkan Campbell (Campbell, 2012) mendefinisikan aspek kelancaran mental merupakan berpikir dari segala arah dan ke segala arah. Menurut pendapatnya bahwa kelincahan mental adalah kemampuan untuk bermain dengan ide - ide, konsep, lambang, kata - kata, angka dan khususnya melihat hubungan yang tidak biasa antar hal tersebut. Pendapat lain dari Karakelle, ia mengatakan bahwa kelancaran dalam berpikir dapat didefinisikan sebagai kuantitas ide-ide yang tidak konvensional dan terkait yang dihasilkan pada masalah tertentu, atau jumlah asosiasi yang dihasilkan sebagai respons terhadap stimulan. Individu yang kreatif diharapkan untuk berpikir secara efektif dan mengembangkan rantai asosiasi yang kaya.

Berikutnya adalah aspek keluwesan berpikir (flexibility), yaitu kemampuan untuk memproduksi sejumlah ide, jawaban-jawaban atau pertanyaan-pertanyaan yang bervariasi, dapat melihat suatu masalah dari sudut pandang yang berbeda - beda, mencari alternatif atau arah yang berbeda-beda, serta mampu menggunakan bermacam-macam pendekatan atau cara vmibm pemikiran. Orang yang kreatif adalah orang yang luwes dalam berpikir. Mereka dengan mudah dapat meninggalkan cara berpikir lama dan menggantikannya dengan cara berpikir yang baru. Fleksibilitas mengarah ke beragam ide-ide yang menggunakan berbagai kategori konseptual(Runco \& Acar, 2012). Elaborasi (elaboration), yaitu kemampuan dalam mengembangkan gagasan dan menambahkan atau memperinci detail-detail dari suatu objek, gagasan atau situasi sehingga menjadi lebih menarik. Keterperincian dalam berpikir merupakan kemampuan untuk memperkaya, mengembangkan, menambah suatu gagasan, memperinci detail-detail dan memperluas suatu gagasan. Elaborasi, yang paling umum, disarankan ketika individu mengikuti jalur asosiatif untuk jarak tertent (Runco \& Acar, 2012). Originalitas (originality), yaitu kemampuan untuk mencetuskan gagasan unik atau kemampuan untuk mencetuskan gagasan asli, yang lain dari yang lain, yang diberikan kebanyakan orang (Munandar, 2009). Orisinalitas biasanya didefinisikan dalam hal kebaruan atau infrekuensi statistic (Runco \& Acar, 2012).

Sedangkan ciri nonaptitude adalah yang berhubungan dengan sikap atau perasaan yaitu: (1) rasa ingin tahu, (2) bersifat imajinatif, (3) merasa tertantang oleh kemajemukan, (4) sifat berani mengambil resiko, (5) sifat menghargai (Munandar, 2009). Orang yang kreatif tidak selalu orang yang dapat menghasilkan suatu produk benda, kreatifitas juga dapat berupa keluwesan, keterampilan berpikir dan ide - ide solusi serta pemecahan masalah.

Berpikir divergen atau memiliki banyak ide atau solusi pada suatu masalah, adalah keterampilan kognitif manusia yang mendasar. Sejak usia dini anak-anak dihadapkan dengan masalah yang membutuhkan berbagai macam solusi baru. Berpikir divergen pada anak dapat dikembangkan dengan berbagai stimulasi. Sesuai dengan usia perkembangannya, pada usia dini stimulasi yang sesuai adalah melalui kegiatan bermain. Sudono (Sudono, 2000) menjelaskan bermain adalah suatu kegiatan yang dilakukan dengan atau tanpa menggunakan alat yang menghasilkan pengertian atau memberikan informasi, memberi rangsangan maupun mengembangkan imajinasi pada anak. Berarti dalam bermain anak memiliki nilai kesempatan untuk mengekspresikan sesuatu yang ia rasakan dan pikirkan. Kegiatan bermain sebenarnya anak sedang mempraktekkan mendapatkan kepuasan dalam bermain, yang berarti mengembangkan dirinya sendiri. Bermain melatih dan merangsang berbagai kemampuan yang ada pada diri anak. Macam-macam permainan 
yang digunakan anak-anak untuk merangsang dan melatih kemampuan anak. Menurut Singer dan Singer memandang bermain sebagai praktek berpikir divergen (Hoffmann \& Russ, 2012).

Freud memandang bermain sama seperti fantasi atau lamunan. Melalui bermain atau fantasi, seseorang dapat memproyeksikan harapan - harapan mapun konflik pribadi. Pandangan lain dari Piaget, ia mengatakan bahwa anak menjakani tahapan prkembangan kognisi sampai akhirnya proses berpikir anak menyamai proses berpikir orang dewasa. Sejalan dengan tahapan perkembangan kognisinya, kegiatan brmain mengakami perubahan dari tahap sensori-motor, bermain khayal sampai kepada bermain sosial yang disertai aturan permainan (Tedjasaputra, 2001). Menurut Heidemann \& Hewit, bermain pada usia prasekolah seringkali dipusatkan pada penggunaan objek. Manfaat praktis dari bermain adalah memfasilitasi tugas - tugas perkembangan anak usia prasekolah dan sekolah (Hurlock dalam Dahlan, 2010), salah satunya adalah mendukung perkembangan kognitif. Melalui aktivitas bermain, seorang anak dapat memperoleh banyak informasi dan pengetahuan tentang lingkungannya. Selanjutnya, mereka dapat menggunakannya pada saat menghadapi kendala dalam kelompok bermain.

Salah satu kegiatan bermain yang mengajak anak mengalami proses kognitif adalah pretend play atau bermain pura- pura. Suminar menyatakan dalam jurnalnya pretend play adalah bentuk permainan yang didalamnya mengandung unsur berpura-pura. Permainan ini berbeda dengan role play, karena dalam pretend play selain terdapat sejumlah aturan, digunakan sejumlah peralatan tertentu yang menunjang permainan. Dengan demikian, kalau dalam role play penekanannya lebih pada peran yang dimainkan, maka dalam pretend play lebih pada peralatan yang dipakai dan yang menunjang unsur "pura-pura" yang ada dalam permainan (Suminar, 2009). Pretend play mengajak anak mengalami proses kognitif dan afektif. Melalui bermain anak dapat mengembangkan kemampuan berpikirnya dan berekspresi saat berpura - pura menirukan sebuah benda atau tokoh tertentu. Anak dapat bereksplorasi memanfaatkan benda yang ada di sekitarnya. Ketika anak melakukam imajinasi berpura - pura menjadi peran tertentu anak akan membayangkan ciri - cirinya yang akan diekspresikan hingga menyerupai peran tersebut. Hal ini seperti yang terdapat dalam penelitiannya Russ menyatakan bahwa kreativitas berkaitan dengan proses kognitif dan afektif. Anak mengalami proses kognitif ketika berimajinasi, menyimbolkan dan mengoranisasikan cerita untuk dimainkan. Anak mengalami proses afektif saat mengekspresikan cerita yang dimainkan (Fehr, Russ, \& Russ, 2016).

Bermain dramatik/ simbolik atau berpura -pura (pretend play) merupakan jenis permainan pada anak - anak berada tahap perkembangan praoperasional, seperti berpura pura menjadi orang lain atau menggunakan objek pura - pura (Masnipal, 2013). Russ (Sansanwal, 2014) menyatakan bahwa bermain pura-pura adalah bentuk permainan yang menggunakan persepsi anak tentang dunia dan fantasi untuk melambangkan satu objek dengan yang lain. Pendapat tersebut menyatakan dalam bermain pura - pura anak menirukan perilaku, ciri - ciri objek tertentu melalui informasi atau pengetahuan yang telah dimiliki anak. Piaget (Masnipal, 2013) menyatakan bahwa perilaku bermain pura - pura muncul dalam bentuk yang berbeda - beda, yaitu bermain pura - pura sendiri (solitary pretend play), dan (social pretend play) dalam bentuk sosiodrama (sosiodramatic play). Social pretend play melibatkan sekelompok orang, bisa orang dewasa seperti guru, kakak kelas, atau teman sebaya. sebagai contoh tipe bermain soial seperti bermain masak masakan, perang - perangan, atau sekolah - sekolahan.

Pretend play melatih kognitif anak dalam mengembangkan berbagai ekspresi. Anak mempunyai informasi mengenai tokoh tersebut kemudian menganalisa bagaimana perasaan, gerak, perilaku untuk memerankan karakter atau tokoh tersebut. Proses membayangkan, menganalisa dan menentukan ciri - ciri karakter atau tokoh tersebut merupakan bagian dari proses kognitif. Anak juga dapat menggali ide terhadap alat bermain pura - pura yang digunakan. Bermain pura - pura memberikan kesempatan anak 
untuk berimajinasi terhadap benda - benda yang ada di sekitarnya, misalnya saat bermain pura - pura anak dapat menggunakan hula hoop yang diumpamakan sebagai setir mobil. Anak berusaha mencari cara untuk mewujudkan imajinasinya dalam memerankan pengendara mobil.

Peneliti melakukan observasi awal mengenai kreativitas di salah satu Taman KanakKanak yang berada Kecamatan Cakung Jakarta Timur. Hasil pengamatan terlihat di kelas bahwa perkembangan kreativitas belum berkembang dengan baik. Sebagian besar anak belum mempunyai rasa ingin tau yang tinggi, berimajinasi serta menuangkan ide - idenya saat bermain. Anak terlihat hanya mengikuti instruksi guru dan bersifat pasif. Saat bermain, terlihat sebagian besar anak tidak memanfaatkan alat - alat di sekitarnya untuk bermain. Dari 19 anak terdapat 21\% anak yang dapat mengutarakan idenya saat bermain. Ketika diberikan kesempatan mengutarakan ide, beberapa anak terlihat pasif hanya mengikuti jawaban teman. Berdasarkan hal tersebut, maka guru perlu memberikan stimulasi yang tepat kepada muridnya sehingga baik laki-laki maupun perempuan dapat mengembangkan kemampuan berpikir divergen mereka dengan maksimal. Olehnya itu, peneliti tertarik untuk mengangkat judul penelitian pada tesis ini yaitu "Pengaruh pretend play dan jenis kelamin terhadap kemampuan berpikir divergen anak usia 5 - 6 tahun" (Penelitian Eksperimen di Taman Kanak Kanak Kristen Cahaya Bangsa Jakarta Timur Tahun Ajaran 2018/2019).

\section{METODOLOGI}

Penelitian ini dilaksanakan dengan metode eksperimen dengan pendekatan kuantitatif. Adapun tujuan penggunaan metode eksperimen dalam penelitian ini adalah untuk melihat adanya pengaruh antara variabel - variabel terkait. Penelitian ini ada dua kelompok eksperimen melakukan pretend play (A1) dan kelompok kontrol tidak diberikan pretend play (A2).

Penelitian ini dilakukan di dua kelas di TK Cahaya Bangsa di Jakarta Timur. Kelas Eksperimen mendapat perlakuan yang berbeda dengan kelas kontrol, di mana kelas eksperimen ini dalam pembelajarannya akan menggunakan bermain pura - pura (Pretend Play) dan kelas kontrol akan menggunakan tidak akan diberikan pretend play dan variabel atribut jenis kelamin yaitu laki - laki dan perempuan.

Desain penelitian ini menggunakan rancangan desain faktorial 2x2. Menurut Emzir, desain faktorial melibatkan dua atau lebih variabel bebas, dan sekurangnya satu yang dimanipulasi oleh peneliti. Pada dasarnya desain ini merupakan elaborasi dari desain true eksperimental dan mengizinkan penyelidikan terhadap dua atau lebih variabel, secara individual dan dalam interaksi satu sama lain (Emzir, 2013). Desain faktorial yang paling sederhana $2 \times 2$, dengan variabel bebas dibentuk menjadi dua sisi, yaitu sisi pertama variabel perlakuan pretend play (A). Sisi kedua variabel bebas atribut yaitu jenis kelamin yang diklasifikasikan menjadi dua yaitu tinggi dan rendah (B). Sesuai dengan desain penelitian diatas, konselasi variabel penelitian dapat dilihat pada rancangan berikut:

Tabel 1.1 Konselasi Variabel Penelitian

\begin{tabular}{ccc}
\hline Pretend play & Pretend play & Tidak diberikan pretend play \\
\hline Jenis Kelamin & A1, B1 & A2, B1 \\
Laki - Laki (B1) & A1, B2 & A2, B2 \\
Perempuan (B2) &
\end{tabular}

Keterangan:

$\begin{array}{lll}\text { 1. } & \text { Variabel terikat } & \text { : Kreativitas (Y) } \\ \text { 2. } & \text { Variabel bebas } & \text { : Pretend play (X1) } \\ \text { 3. } & \text { Variabel Atribut } & \text { : Jenis kelamin (X2) }\end{array}$


Populasi dalam penelitian ini adalah seluruh anak usia dini pada jenjang pendidikan Taman Kanak-Kanak se Jakarta Timur tahun pelajaran 2018/2019. Populasi terjangkau adalah seluruh anak usia dini yang terdapat di Taman Kanak-Kanak Kristen Cahaya Bangsa Jakarta Timur Tahun Ajaran 2018/2019. Sampel dalam penelitian ini yaitu anak kelas TKB 1 (orange), TKB 2 (apple) di Taman Kanak-Kanak Kristen Cahaya Bangsa tahun pelajaran 2018/2019.

Teknik pengambilan sampel dilakukan dengan teknik multi stage simple random sampling, yang meliputi: 1) memilih secara acak Kecamatan yang ada di Jakarta Timur 2) mengumpulkan nama-nama Sekolah Dasar yang ada di kecamatan Cakung (dari hasil pemilihan secara random), kemudian melakukan simple random sampling terhadap namanama sekolah tersebut; 3) menetapkan sekolah terpilih untuk dijadikan tempat penelitian 4) menetapkan jenjang TK B, kemudian melakukan simple random sampling kembali untuk menentukan kelas eksperimen; 5) terpilih kelas orange sebagai kelas eksperimen dan kelas apple sebagai kelas kontrol. Sehingga satu kelas baik yang diberikan pretend play dan tidak akan dibagi berdasarkan kelompok jenis kelamin, laki - laki dan perempuan. Dari jumlah 39 (tiga puluh sembilan) anak terbentuk 4 (empat) sel dari kedua kelompok yakni: (1) Kelompok anak diberikan pretend play yang berjenis kelamin laki - laki dengan jumlah sampel 11 anak (A1B1), (2) Kelompok anak tidak diberikan pretend play yang berjenis kelamin laki - laki dengan jumlah 10 anak (A2B1), (3) Kelompok anak diberikan pretend play yang berjenis kelamin perempuan dengan jumlah sampel 9 anak (A1B2), dan (4) Kelompok anak tidak diberikan pretend play yang berjenis kelamin perempuan dengan jumlah sampel 9 anak (A2B2).

Di dalam penelitian ini terdapat satu jenis perlakuan, yaitu dengan memberikan kegiatan bermain. Jenis bermain yang digunakan adalah pretend play. Untuk pretend play diberikan pada anak Kelas B Orange sedangkan TK B Apple tidak diberikan pretend play. Perlakuan untuk di masing - masing kelas akan diberikan oleh peneliti dan guru kelas (kolaboratif). Penelitian ini dilaksanakan sesuai dengan jadwal Rencana Pelaksanaan Pembelajaran (RPP) Taman Kanak-Kanak Kristen Cahaya Bangsa Jakarta Timur. Penelitian ini akan dilaksanakan pada semester ganjil selama dua bulan atau 8 (delapan) minggu dengan frekuensi perlakuan dua atau tiga kali seminggu. Total keseluruhan jumlah pertemuan adalah sebanyak 16 kali pertemuan. Rincian kegitan meliputi: (1) Pelaksanaan observasi awal untuk pengambilan data yaitu observasi untuk mengetahui kemampuan divergen anak sebagai dasar pengelompokan sampel penelitian, (2) Pelaksanaan eksperimen tentang pretend play (3) Pelaksanaan observasi akhir yaitu untuk memperoleh data mengenai kemampuan berpikir divergen anak.

Peneliti menyiapkan beberapa instrumen dan panduan penggunaanya yang akan diberikan ke guru kelas. Instrumen yang akan digunakan berupa panduan observasi dan skala penilaian. Pengambilan data dilakukan setelah mendapat perlakuan. Skala penilaian dengan deskripsi kemampuan yang dicapai anak. Lembar observasi ini digunakan untuk mengetahui tingkat kemampuan berpikir divergen. Lembar pengamatan dilengkapi dengan kisi - kisi serta rubrik penilaian.

Pada bagian analisis meliputi analisis deskriptif dan analisis inferensial. Analisis deskriptif terdiri dari data setiap variabel dalam besaran-besaran statistik seperti rata-rata (mean), nilai tengah (median), frekuensi terbanyak (modus), simpangan baku (standar deviasi), dan menvisualisasikan ke dalam bentuk tabel distribusi frekuensi dan histogram, sedangkan analisis infrensial merupakan statistik yang digunakan untuk pengujian hipotesis. Pengujian hipotesis digunakan teknik analisis varians (ANAVA) dua jalur $2 \times 2$ pada taraf signifikan $a=0,05$. Apabila uji anava terdapat pengaruh yang signifikan dari setiap faktor perlakuan dan interaksinya, dilanjutkan dengan uji Dunnet. Uji hipotesis dilakukan setelah melakukan uji persyaratan analisis data yaitu menguji normalitas data yang diperoleh dari hasil penerapan pretend play dan jenis kelamin terhadap kemampuan berpikir divergen anak digunakan uji Liliefors. Untuk uji homogenitas menggunakan uji 
Barlett atau Levene Statistic pada analisis homogenitas varian data homogen jika $p>0,05$ dan tidak homogen jika $\mathrm{p}<0,05$.

Setelah mengikuti proses kegiatan bermain pretend play dengan kelompok eksperimen diberikan pretend play dan kelompok control tidak pretend play, maka diperoleh kemampuan berpikir divergen anak berupa skor.

\section{HASIL DAN PEMBAHASAN}

\section{Kelompok Anak yang Diberi Pretend play $\left(\mathrm{A}_{1}\right)$}

Berdasarkan pada data yang telah dikumpulkan dari responden sebanyak 20 orang anak, diperoleh data kelompok anak yang diberi pretend play dengan perolehan skor tertinggi 98 , skor terendah 76 rata-rata 80,50 , nilai median 86 , nilai modus 78 , dan simpangan baku 6,78.

\section{Kelompok Anak Yang Tidak Diberi pretend play $\left(\mathrm{A}_{2}\right)$}

Berdasarkan pada data yang telah dikumpulkan dari responden sebanyak 19 orang anak, diperoleh data kelompok anak yang tidak diberi pretend play dengan perolehan skor tertinggi 83 , skor terendah 64 , rata-rata 70,55, nilai median 70, nilai modus 67 dan simpangan baku 4,29 .

\section{Kelompok Anak Yang Memiliki Jenis kelamin Laki-laki (B1)}

Berdasarkan pada data yang telah dikumpulkan dari responden sebanyak 21 orang anak, diperoleh data kelompok anak yang memiliki jenis kelamin laki-laki dengan perolehan skor tertinggi 87 , skor terendah 64 , rata-rata 73,31, nilai median 77 , nilai modus 80 , dan simpangan baku 7,08 .

\section{Kelompok Anak yang Memiliki Jenis kelamin Perempuan $\left(\mathbf{B}_{2}\right)$}

Berdasarkan pada data yang telah dikumpulkan dari responden sebanyak 18 orang anak, diperoleh data kelompok anak yang memiliki jenis kelamin perempuan dengan perolehan skor tertinggi 98 , skor terendah 67 , rata-rata 77,36 , nilai median 80 , nilai modus 67 , dan simpangan baku 11,36.

Kelompok Anak yang Diberi Metode bermain Pura-pura dengan Pretend play dan yang Memiliki Jenis kelamin Laki-laki $\left(\mathrm{A}_{1} \mathrm{~B}_{1}\right)$

Berdasarkan pada data yang telah dikumpulkan dari responden sebanyak 11 orang anak, diperoleh data kelompok anak yang diberi metode bermain Pura-pura dengan pretend play dan yang memiliki jenis kelamin laki-laki dengan perolehan skor tertinggi 87, skor terendah 76 , rata-rata 80,82 , nilai median 80 , nilai modus 78 , dan simpangan baku 8,44.

Kelompok Anak yang Diberi Metode bermain Pura-pura dengan Pretend play dan yang Memiliki Jenis kelamin Perempuan $\left(A_{1} B_{2}\right)$

Berdasarkan pada data yang telah dikumpulkan dari responden sebanyak 9 orang anak, diperoleh data kelompok anak yang diberi metode bermain Pura-pura dengan pretend play dan yang memiliki jenis kelamin perempuan dengan perolehan skor tertinggi 98, skor terendah 81, rata-rata 93,78, nilai median 91, nilai modus 91, dan simpangan baku 5,20.

Kelompok Anak yang Diberi Metode bermain Pura-pura dengan Tidak pretend play dan yang Memiliki Jenis kelamin Laki-laki $\left(\mathrm{A}_{2} \mathrm{~B}_{1}\right)$

Berdasarkan pada data yang telah dikumpulkan dari responden sebanyak 10 orang anak, diperoleh data kelompok anak yang diberi metode bermain Pura-pura dengan tidak pretend play dan yang memiliki jenis kelamin laki-laki dengan perolehan skor tertinggi 80 , skor terendah 64, rata-rata 71,10, nilai median 69, nilai modus 68, dan simpangan baku 5,08. 


\section{Kelompok Anak Yang Tidak Diberi pretend play Dan Yang Memiliki Jenis kelamin Perempuan $\left(\mathrm{A}_{2} \mathrm{~B}_{2}\right)$}

Berdasarkan pada data yang telah dikumpulkan dari responden sebanyak 9 orang anak, diperoleh data kelompok anak yang tidak diberikan pretend play dan yang memiliki jenis kelamin perempuan dengan perolehan skor tertinggi 78 , skor terendah 67 , rata-rata 70,33, nilai median 70, nilai modus 67 dan simpangan baku 3,50.

Tabel 2. Data Kemampuan berpikir Divergen Anak

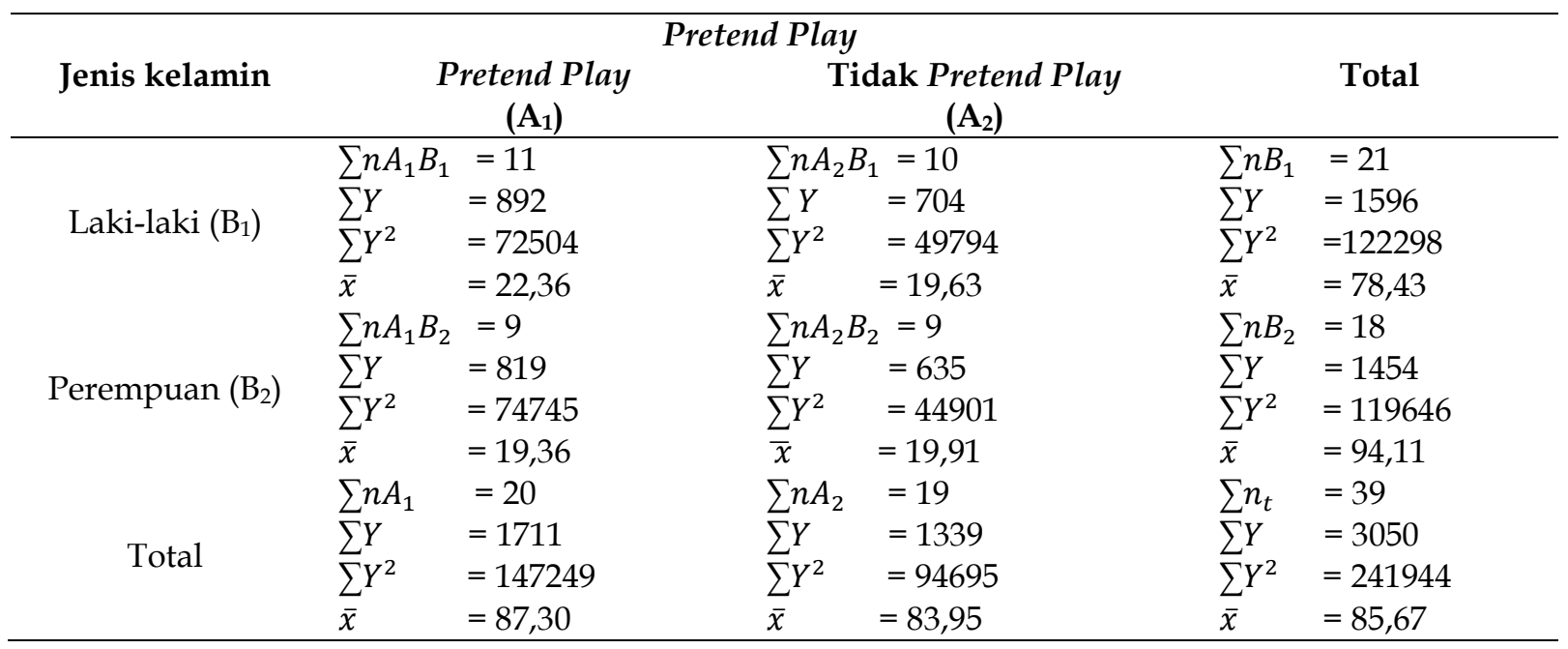

Berdasarkan hasil perhitungan normalitas data pada semua kelompok penelitian diketahui bahwa Lhitung untuk semua kelompok lebih kecil dari Ltabel, ini berarti bahwa pada semua kelompok penelitian berdistribusi normal. Hasil perhitungan uji normalitas dengan uji Lilliefors secara keseluruhan dapat dilihat pada tabel berikut.

Tabel 3. Rekapitulasi Hasil Uji Normalitas Sampel dengan Uji Lilliefors pada Taraf $\alpha=0,05$

\begin{tabular}{ccccc}
\hline Kelompok & Jumlah Sampel & $\begin{array}{c}\text { Lhitung } \\
\left(\mathrm{L}_{0}\right)\end{array}$ & $\begin{array}{c}\text { Ltabel } \\
\left(\mathrm{L}_{\mathrm{t}}: \mathrm{a}=0,05\right)\end{array}$ & Kesimpulan \\
\hline $\mathrm{A}_{1}$ & 20 & 0,149 & 0,190 & Normal \\
$\mathrm{A}_{2}$ & 19 & 0,192 & 0,195 & Normal \\
$\mathrm{B}_{1}$ & 21 & 0,157 & 0,190 & Normal \\
$\mathrm{B}_{2}$ & 18 & 0,197 & 0,200 & Normal \\
$\mathrm{A}_{1} \mathrm{~B}_{1}$ & 11 & 0,240 & 0,249 & Normal \\
$\mathrm{A}_{1} \mathrm{~B}_{2}$ & 9 & 0,089 & 0,271 & Normal \\
$\mathrm{A}_{2} \mathrm{~B}_{1}$ & 10 & 0,182 & 0,258 & Normal \\
$\mathrm{A}_{2} \mathrm{~B}_{2}$ & 9 & 0,132 & 0,271 & Normal \\
\hline
\end{tabular}

Rekapitulasi dari hasil perhitungan uji homogenitas data dengan menggunakan Uji Bartlett dimana X2hitung $\leq$ X2tabel pada taraf signifikansi $a=0,05$ dapat dilihat pada tabel berikut:

Tabel 4. Rekapitulasi Uji Homogenitas pada Kelompok-Kelompok Penelitian Menggunakan Uji Bartlett

\begin{tabular}{clccc}
\hline No & \multicolumn{1}{c}{ Kelompok Sampel } & $\mathbf{X}^{2}$ hitung & $\begin{array}{c}\mathbf{X}^{2} \text { tabel } \\
(\mathbf{a}=\mathbf{0}, \mathbf{0 5})\end{array}$ & Kesimpulan \\
\hline $\mathbf{1}$ & Kelompok $\mathrm{A}_{1}$ dan $\mathrm{A}_{2}$ & 0,96 & 3,84 & Homogen \\
$\mathbf{2}$ & Kelompok $\mathrm{B}_{1}$ dan $\mathrm{B}_{2}$ & 1,03 & 3,84 & Homogen \\
$\mathbf{3}$ & Kelompok $\mathrm{A}_{1} \mathrm{~B}_{1}, \mathrm{~A}_{1} \mathrm{~B}_{2}, \mathrm{~A}_{2} \mathrm{~B}_{1}$ & 0,42 & 7,82 & Homogen \\
& \begin{tabular}{l} 
dan $\mathrm{A}_{2} \mathrm{~B}_{2}$ \\
\hline
\end{tabular}
\end{tabular}


Selanjutnya dalam penelitian ini uji homogenitas varian menggunakan uji Bartlett yang dilakukan terhadap dua kelompok data variabel perlakuan yaitu uji homogenitas varian pada kelompok A1 dan A2 (metode bermain Pura-pura), dua kelompok data variabel atribut yaitu uji homogenitas varian pada kelompok B1 dan B2 (jenis kelamin) dan empat kelompok data sel pada rancangan eksperimen yaitu uji homogenitas varian dari kelompok A1B1, A1B2, A2B1 dan A2B2.

Tabel 5. Rangkuman Hasil Perhitungan Uji Homogenitas Kelompok $\mathbf{A}_{1} \mathbf{B}_{1}, \mathbf{A}_{1} \mathbf{B}_{2}, \mathbf{A}_{2} \mathbf{B}_{1}$ dan $\mathbf{A}_{2} \mathbf{B}_{2}$

\begin{tabular}{cccccccc}
\hline Sampel & $\mathbf{n}$ & $\mathbf{d b}$ & $\mathbf{1} / \mathbf{d b}$ & $\mathbf{s i}^{\mathbf{2}}$ & $\mathbf{d b} . \mathbf{s i} \mathbf{2}^{\mathbf{2}}$ & $\mathbf{l o g} \mathbf{s i}$ & $\mathbf{d b} \cdot \mathbf{l o g}\left(\mathbf{s i}^{\mathbf{2}} \mathbf{)}\right.$ \\
\hline $\mathbf{A}_{\mathbf{1}} \mathbf{B}_{\mathbf{1}}$ & 11 & 10 & 0,10 & 8,71 & 87,07 & 0,94 & 9,40 \\
$\mathbf{A}_{\mathbf{2}} \mathbf{B}_{\mathbf{1}}$ & 10 & 9 & 0,11 & 9,59 & 86,32 & 0,98 & 8,84 \\
$\mathbf{A}_{\mathbf{1}} \mathbf{B}_{2}$ & 9 & 8 & 0,13 & 2,51 & 20,04 & 0,40 & 3,19 \\
$\mathbf{A}_{\mathbf{2}} \mathbf{B}_{2}$ & 9 & 8 & 0,13 & 4,56 & 36,44 & 0,66 & 5,27 \\
Jumlah & $\mathbf{3 9}$ & $\mathbf{3 5}$ & $\mathbf{0 , 4 6}$ & & $\mathbf{2 2 9 , 8 8}$ & & $\mathbf{2 6 , 7 0}$ \\
\hline
\end{tabular}

Berdasarkan hasil perhitungan Uji Bartlett diperoleh $\mathrm{X}^{2}{ }_{\text {hit }}=4,41$. Dari daftar tabel distribusi Chi-Kuadrat, $\mathrm{X}^{2}{ }_{\text {tab }}(\mathrm{a}=0,05)(3)=7,82$. Dengan demikian diperoleh $\mathrm{X}^{2}{ }_{\text {hit }}<\mathrm{X}^{2}{ }_{\text {tab }}, \mathrm{H}_{0}$ diterima, ini berarti kemampuan berpikir Divergen anak dari keempat kelompok tersebut berasal dari populasi yang homogen. Dari hasil pengujian normalitas dan homogenitas data penelitian dapat disimpulkan bahwa data berasal dari populasi yang berdistribusi normal dan homogen sehingga dapat dilanjutkan dengan pengujian hipotesis.

Berdasarkan perhitungan yang telah dilakukan secara manual menggunakan ANAVA dua jalan diperoleh analisis seperti pada tabel di bawah ini:

Tabel 4.15 Hasil Analisis Varians Menggunakan ANAVA Dua Jalan

\begin{tabular}{cccccccc}
\hline Sumber varians & JK & Db & RJK & $F_{\text {hitung }}$ & $F_{\text {tabel }(0.05)}$ & $\begin{array}{c}\mathrm{F}_{\text {tabel }} \\
(0.01)\end{array}$ & Kesimpulan \\
\hline Antar A & 2700.828 & 3 & 900.276 & 43.914 & 2.874 & 4.396 & $\mathrm{H}_{\mathrm{o}}$ ditolak \\
\hline Antar A $_{(\mathrm{k})}$ & 2214.672 & 1 & 2214.672 & 108.028 & 4.121 & 7.419 & $\mathrm{H}_{\mathrm{o}}$ ditolak \\
\hline Antar A $(\mathrm{b})$ & 221.248 & 1 & 221.248 & 10.792 & 4.121 & 7.419 & $\mathrm{H}_{\mathrm{o}}$ ditolak \\
\hline Interaksi AB & 360.997 & 1 & 360.997 & 17.609 & 4.121 & 7.419 & $\mathrm{H}_{\mathrm{o}}$ ditolak \\
\hline Dalam & 717.531 & 35 & 20.501 & & & & \\
\hline Total Reduksi & & 38 & & & & &
\end{tabular}

Berdasarkan hasil analisis varians (ANAVA) dua jalur di atas, maka pengujian hipotesis dapat dijelaskan sebagai berikut:

\section{Pengaruh Utama (Main Effect)}

Dari hasil analisis diketahui nilai $\mathrm{F}(\mathrm{OA})=43,914$. Dari tabel Daftar-G pada $\mathrm{db}(\mathrm{A}) / \mathrm{db}$ $(D)=3 / 35$ dan $\alpha=0,05$ diketahui nilai Ftabel $=2,874$. Karena $F(O A)=16,378>$ Ftabel $=2,874$ atau H0 ditolak, jadi terdapat perbedaan rata-rata kemampuan berpikir Divergen anak antara kelompok anak yang diberi metode bermain Pura-pura dengan pretend play dan kelompok anak yang tidak diberi pretend play. Dari hasil analisis diketahui nilai $\mathrm{F}(\mathrm{OB})=$ 10.792. Dari tabel Daftar-G pada $d b(A) / d b(D)=1 / 35$ dan $a=0,05$ diketahui nilai Ftabel $=$ 4,121 . Karena $F(O A)=46,289>$ Ftabel $=4,121$ atau H0 ditolak, jadi terdapat perbedaan rata- 
rata kemampuan berpikir Divergen anak antara kelompok anak yang memiliki jenis kelamin laki-laki dan kelompok anak yang memiliki jenis kelamin perempuan.

\section{Pengaruh Interaksi (Interaction Effect)}

Dari hasil analisis diketahui nilai $\mathrm{F}(\mathrm{OAB})=17,609$. Dari tabel Daftar-G pada $\mathrm{db}$ $(\mathrm{A}) / \mathrm{db}(\mathrm{D})=1 / 35$ dan $a=0,05$ diketahui nilai Ftabel $=4,121$. Karena $F(O A B)=17,609>$ Ftabel $=4,121$ atau $\mathrm{H0}$ ditolak, jadi terdapat pengaruh interaksi yang signifikan antara faktor A (pretend play) dan faktor B (jenis kelamin) terhadap kemampuan berpikir divergen anak anak.

Dunnet:

Dari hasil analisis terdapat interaksi, maka perlu dilakukan uji lanjut dengan uji t-

Tabel 4.16 Rekapitulasi Hasil Perhitungan Uji t - Dunnet

\begin{tabular}{ccc}
\hline Kelompok Perbandingan & $\mathbf{t}_{\text {hitung }}$ & $\mathbf{t}_{\text {tabel }}(\mathbf{a}=\mathbf{0 , 0 5 ; 3 5 )}$ \\
\hline $\mathrm{A}_{1} \mathrm{~B}_{1}$ dan $\mathrm{A}_{2} \mathrm{~B}_{1}$ & 1,957 & 1,697 \\
$\mathrm{~A}_{1} \mathrm{~B}_{2}$ dan $\mathrm{A}_{2} \mathrm{~B}_{2}$ & 2,478 & 1,697 \\
$\mathrm{~A}_{1} \mathrm{~B}_{1}$ dan $\mathrm{A}_{1} \mathrm{~B}_{2}$ & $-5,271$ & 1,697 \\
$\mathrm{~A}_{2} \mathrm{~B}_{1}$ dan $\mathrm{A}_{2} \mathrm{~B}_{2}$ & $-4,549$ & 1,697 \\
\hline
\end{tabular}

Berdasarkan hasil perhitungan yang sudah ada dilakukan, maka dapat kita simpulkan uji hipotesis sebagai berikut:

Hipotesis Pertama: Kemampuan berpikir Divergen anak pada kelompok anak yang diberi pretend play lebih tinggi dibandingkan dengan kelompok anak yang tidak diberi pretend play.

Hipotesis ini diterima setelah didapat melalui hasil perhitungan data menggunakan ANAVA dua jalan dengan menggunakan kriteria pengujian $\mathrm{H}_{0}\left(\mathrm{H}_{0}: \mu \mathrm{A}_{1} \leq \mu \mathrm{A}_{2}\right)$ ditolak dan $\mathrm{H}_{1}\left(\mathrm{H}_{1}: \mu \mathrm{A}_{1}>\mu \mathrm{A}_{2}\right)$ diterima pada $\alpha=0,05$ berdasarkan hasil perhitungan ANAVA dua jalan diketahui bahwa nilai $\mathrm{F}_{\text {hitung }}=43,914>\mathrm{F}_{\text {tabel }}=2,878$ yang berarti $\mathrm{H}_{0}$ ditolak dan $\mathrm{H}_{1}$ diterima pada $a=0,05$. Dengan demikian dapat disimpulkan bahwa kemampuan berpikir Divergen anak pada kelompok anak yang diberi metode bermain Pura-pura dengan pretend play lebih tinggi dari pada kemampuan berpikir Divergen anak pada kelompok anak yang diberi metode bermain Pura-pura dengan tidak pretend play.

Hipotesis Kedua: Kemampuan berpikir Divergen anak pada kelompok anak yang memiliki jenis kelamin laki-laki yang diberi pretend play lebih rendah dibandingkan dengan kelompok anak yang memiliki jenis kelamin Perempuan yang diberi pretend play.

Hipotesis ini diterima setelah didapat melalui hasil perhitungan data menggunakan ANAVA dua jalan dengan menggunakan kriteria pengujian $\mathrm{H}_{0}\left(\mathrm{H}_{0}: \mu \mathrm{A}_{1} \mathrm{~B}_{1} \geq \mu \mathrm{A}_{1} \mathrm{~B}_{2}\right)$ ditolak dan $\mathrm{H}_{1}\left(\mathrm{H}_{1}: \mu \mathrm{A}_{1} \mathrm{~B}_{1}<\mu \mathrm{A}_{1} \mathrm{~B}_{2}\right)$ diterima pada $\alpha=0,05$. Selain itu skor rata-rata kemampuan berpikir Divergen anak pada anak yang diberikan metode bermain Pura-pura dengan pretend play dan yang memiliki jenis kelamin laki-laki $\left(\mathrm{A}_{1} \mathrm{~B}_{1}\right)$ sebebsar 80,82 lebih rendah dari pada skor rata-rata kemampuan berpikir Divergen anak pada anak yang diberi metode bermain Pura-pura dengan pretend play dan yang memiliki jenis kelamin perempuan $\left(\mathrm{A}_{1} \mathrm{~B}_{2}\right)$ sebesar 93,78. Sehingga berdasarkan hasil perhitungan uji lanjut dengan uji $t$-Dunnet diperoleh nilai $t_{\text {hitung }}=-5,271<t_{\text {tabel }}=1,697$ yang berarti bahwa $\mathrm{H}_{0}$ ditolak dan $\mathrm{H}_{1}$ diterima pada $\alpha=0,05$.

Dengan demikian dapat disimpulkan bahwa kemampuan berpikir Divergen anak pada kelompok anak yang diberi pretend play dan yang memiliki jenis kelamin laki-laki lebih rendah daripada kemampuan berpikir Divergen anak pada kelompok anak yang diberi pretend play dan yang memiliki jenis kelamin perempuan. 
Hipotesis Ketiga: Kemampuan berpikir Divergen anak pada kelompok anak yang memiliki jenis kelamin laki-laki dan yang diberi dengan pretend play lebih tinggi dibandingkan dengan kelompok anak tidak diberi pretend play.

Hipotesis ini diterima setelah didapat melalui hasil perhitungan data menggunakan ANAVA dua jalan dengan menggunakan kriteria pengujian $\mathrm{H}_{0}\left(\mathrm{H}_{0}: \mu \mathrm{A}_{1} \mathrm{~B}_{1} \leq \mu \mathrm{A}_{2} \mathrm{~B}_{1}\right)$ ditolak dan $H_{1}\left(H_{1}: \mu A_{1} B_{1}>\mu A_{2} B_{1}\right)$ diterima pada $\alpha=0,05$. Selain itu skor rata-rata kemampuan berpikir Divergen anak pada anak yang diberikan pretend play dan yang memiliki jenis kelamin laki-laki $\left(\mathrm{A}_{1} \mathrm{~B}_{1}\right)$ sebesar 80,82 lebih tinggi daripada skor rata-rata kemampuan berpikir Divergen anak pada anak yang diberi metode bermain Pura-pura dengan tidak pretend play dan yang memiliki jenis kelamin laki-laki $\left(\mathrm{A}_{2} \mathrm{~B}_{1}\right)$ sebesar 71,10 . Sehingga berdasarkan hasil perhitungan uji lanjut dengan uji $t$-Dunnet diperoleh nilai $t_{\text {hitung }}=1,957>$ $t_{\text {tabel }}=1,697$ yang berarti bahwa $\mathrm{H}_{0}$ ditolak dan $\mathrm{H}_{1}$ diterima pada $\mathrm{a}=0,05$.

Dengan demikian dapat disimpulkan bahwa kemampuan berpikir Divergen anak pada kelompok anak yang diberi metode bermain Pura-pura dengan pretend play dan yang memiliki jenis kelamin laki-laki lebih tinggi daripada kemampuan berpikir Divergen anak pada kelompok anak yang diberi metode bermain Pura-pura dengan tidak pretend play dan yang memiliki jenis kelamin laki-laki.

Hipotesis Keempat: Kemampuan berpikir Divergen anak pada kelompok anak yang memiliki jenis kelamin perempuan yang diberi pretend play lebih tinggi dibandingkan dengan kelompok anak yang tidak diberi pretend play.

Hipotesis ini diterima setelah didapat melalui hasil perhitungan data menggunakan ANAVA dua jalan dengan menggunakan kriteria pengujian $\mathrm{H}_{0}\left(\mathrm{H}_{0}: \mu \mathrm{A}_{1} \mathrm{~B}_{2} \leq \mu \mathrm{A}_{2} \mathrm{~B}_{2}\right)$ ditolak dan $\mathrm{H}_{1}\left(\mathrm{H}_{1}: \mu \mathrm{A}_{1} \mathrm{~B}_{2}>\mu \mathrm{A}_{2} \mathrm{~B}_{2}\right)$ diterima pada $\alpha=0,05$. Selain itu skor rata-rata kemampuan berpikir Divergen anak pada anak yang diberikan metode bermain Pura-pura dengan pretend play dan yang memiliki jenis kelamin perempuan $\left(\mathrm{A}_{1} \mathrm{~B}_{2}\right)$ sebesar 93,78 lebih tinggi dari pada skor rata-rata kemampuan berpikir Divergen anak pada anak yang diberi metode bermain Pura-pura dengan tidak pretend play dan yang memiliki jenis kelamin perempuan $\left(A_{2} B_{2}\right)$ sebesar 70,33 . Sehingga berdasarkan hasil perhitungan uji lanjut dengan uji $t$-Dunnet diperoleh nilai $t_{\text {hitung }}=2,478>t_{\text {tabel }}=1,697$ yang berarti bahwa $\mathrm{H}_{0}$ ditolak dan $\mathrm{H}_{1}$ diterima pada $\alpha=0,05$.

Dengan demikian dapat disimpulkan bahwa kemampuan berpikir Divergen anak pada kelompok anak yang diberi metode bermain Pura-pura dengan pretend play dan yang memiliki jenis kelamin perempuan lebih tinggi daripada kemampuan berpikir Divergen anak pada kelompok anak yang diberi metode bermain Pura-pura dengan tidak pretend play dan yang memiliki jenis kelamin perempuan.

\section{SIMPULAN}

Berdasarkan hasil penelitian dan pembahasan diperoleh dapat disimpulkan bahwa terdapat pengaruh interaksi antara pretend play dan jenis kelamin terhadap kemampuan berpikir divergen anak. Hal tersebut menyatakan bahwa untuk meningkatkan kemampuan berpikir divergen anak maka penerapan pretend play harus melihat variabel dengan jenis kelamin. Kemampuan berpikir divergen anak laki - laki yang diberikan pretend play lebih tinggi dengan yang tidak diberikan pretend play. Artinya anak laki - laki yang diberikan pretend play kemampuan berpikir divergennya dapat meningkat. Kemampuan berpikir divergen anak perempuan yang diberikan pretend play lebih tinggi dengan yang tidak diberikan pretend play. Artinya anak perempuan yang diberikan pretend play kemampuan berpikir divergennya dapat meningkat. Selanjutnya Anak dengan jenis kelamin laki - laki yang mendapat pretend play memiliki kemampuan berpikir divergen yang lebih rendah dari anak perempuan yang diberikan pretend play. Artinya untuk mengembangkan kemampuan berpikir divergen pada anak laki - laki kurang tepat dengan pretend play. 
Sedangkan untuk mengembangkan kemampuan berpikir divergen anak perempuan lebih tepat dengan diberikan pretend play. Oleh karena itu, untuk meningkatkan kemampuan berpikir divergen anak usia 5 -6 tahun, pemberian pretend play dan memperhatikan jenis kelamin yang dimiliki anak sangat membantu.

\section{UCAPAN TERIMAKASIH}

Terima Kasih kepada seluruh pihak yang telah membantu dalam penyelesaian penelitian ini. Kepada Taman Kanak-Kanak Kristen Cahaya Bangsa atas kerjasamanya sehingga pnelitian ini berhasil dilakukan.

\section{DAFTAR PUSTAKA}

Artola, T. (2015). Boys and Girls Creativity: Qualitative Differences in Divergent Thinking., (April). https://doi.org/10.13140/RG.2.1.4857.2966

Boehm. (2017). https://www.timeshighereducation.com/news/martin-boehm-preparingstudents-for-jobs-that-dont-exist-yet.

Campbell, D. (2012). Membangkan Kreativitas. (A. M. Mangunhardjana, Ed.). Yogyakarta: Kanisius.

Cramond, B., Matthews-morgan, J., Bandalos, D., \& Zuo, L. (2005). A Report on the 40-Year Follow-Up of the Torrance Tests of Creative Thinking. https://doi.org/10.1177/001698620504900402

Emzir. (2013). Metodologi Penelitian Pendidikan Kuantitatif dan Kualitatif. Jakarta: Raja Grafindo Persada.

Fehr, K. K., Russ, S. W., \& Russ, S. W. ". (2016). Pretend Play and Creativity in Preschool-Aged Children: Associations and Brief Intervention Recommended Citation. Psychology of Aesthetics, Creativity, and the Arts, 10(3), 296-308. https://doi.org/10.1037/aca0000054

Florida, R., Mellander, C., \& King, K. (2015). The Global Creativity Index 2015. Martin Prosperity Institute, 68. Retrieved from http://martinprosperity.org/media/Global-CreativityIndex-2015.pdf

Hoffmann, J., \& Russ, S. (2012). Pretend play, creativity, and emotion regulation in children. Psychology of Aesthetics, Creativity, and the Arts, 6(2), 175-184. https://doi.org/10.1037/a0026299

Lee, K. H. (2005). The relationship between creative thinking ability and creative personality of preschoolers. International Education Journal, 6(2), 194-199. https://doi.org/10.1093/nar/26.3.721

Levin-Goldberg, J. (2012). Teaching Generation TechX with the 4Cs: Using Technology to Integrate 21st Century Skills. Journal of Instructional Research, 1, 59-66. Retrieved from http:/ / search.ebscohost.com/login.aspx?direct=true\&db=eric\&AN=EJ1127608\&site=eho st-live

Masnipal. (2013). Siap Menjadi guru dan pengelola PAUD Profesional. Jakarta: Elex Media Komputindo.

Michalopoulou, A. (2014). Creativity Expressed through Drawings in Early Childhood Education. International Journal of Education, 6(2), 69. https:// doi.org/10.5296/ije.v6i2.5328

Munandar, U. (2009). Pengembangan kreativitas anak berbakat. Jakarta: Rineka Cipta.

Rudienė, R., Volkovickienè, V., \& Butvilas, T. (2016). Fostering Creativity in Early Child' S Education, 3137, 145-155. https://doi.org/10.15181/tbb.v73i1.1270.

Runco, M. A., \& Acar, S. (2012). Divergent Thinking as an Indicator of Creative Potential. Creativity Research Journal, 24(1), 66-75. https:// doi.org/10.1080/10400419.2012.652929

Russ, S. W., \& Wallace, C. E. (2013). Pretend Play and Creative Processes. American Journal of Play, 6(1), 136-148. https://doi.org/10.1097/SCS.0b013e318262db2f

Sansanwal, S. (2014). Pretend Play Enhances Creativity and Imagination. Journal of Arts and Humanities, 3(1), 70-83. 